\title{
Entrevista com Maria Elvira Diaz Benitez
}

\author{
Interview with \\ Maria Elvira Diaz Benitez
}

Jainara Gomes de Oliveira

Doutoranda em Antropologia Social - PPGAS/UFSC gomes.jainara@gmail.com

Milton Ribeiro

Doutorando em Sociologia e Antropologia - PPGSA/UFPA millor_ufpa@hotmail.com

\section{Tarsila Chiara A. S. Santana}

Mestranda em Antropologia Social - PPGAS/UFRN tarsila.chiara@gmail.com 


\section{Apresentação}

Entrevista $^{1}$ realizada no Hall do Hotel União, no dia 28 de outubro de 2015, durante o $39^{\circ}$ Encontro Anual da Associação Nacional de Pós-Graduação e Pesquisa em Ciências Sociais, na cidade de Caxambu, Minas Gerais. A antropóloga Maria Elvira Diaz Benitez possui graduação em Antropologia - Universidad Nacional de Colombia (1998), mestrado (2005) e doutorado (2009) em Antropologia Social - Museu Nacional/UFRJ. Entre 2010 e 2013 realizou pós-doutorado no Núcleo de Estudos de Gênero PAGU, da Universidade Estadual de Campinas (Unicamp). É organizadora da Coletânea Prazeres Dissidentes (Garamond/CLAM, 2009), autora do livro Nas Redes do sexo: os bastidores do pornô brasileiro (Zahar, 2010), e co-organizadora do Dossiê Pornôs (Cadernos Pagu, 2012). Atualmente é professora adjunta no Programa de Pósgraduação em Antropologia Social do Museu Nacional da Universidade Federal do Rio de Janeiro (PPGAS/MN/UFRJ), co-coordenadora do NuSEX (Núcleo de Estudos em Corpos, Gêneros e Sexualidade) da mesma instituição e diretora da Coleção Kalela de Antropologia da Papéis Selvagens Edições.

Equatorial: Conte-nos sobre sua formação na Colômbia, seus primeiros interesses de pesquisa.

Maria Elvira Diaz Benitez: Eu me formei na Universidade Nacional da Colômbia, em 1998. Eu entrei à carreira com 16 anos, em janeiro de 1993. O curso durava quatro anos e meio e tínhamos mais um semestre para fazer a tese, tempo que podia se prorrogar por outros seis meses. Nesse quinto ano a gente cursava o Laboratório de Investigação Social em que recebíamos orientação especifica sobre a pesquisa e tinha como objetivo nos encaminhar para a escrita da monografia que lá chamamos de tese, mesmo se tratando de trabalho final da graduação. Quando entrei na universidade, me interessei primeiro pela etnologia, essa era uma temática que me interessou profundamente. Fui aluna de um dos melhores etnólogos da Colômbia, o professor Luis Guillermo Vasco e suas aulas eram muito inspiradoras, depois disso tive aulas de etnohistória com a professora Marta Zambrano, maravilhosas também, com ela vimos Estruturalismo e com François Correa vimos Parentesco, eram aulas realmente muito inspiradoras. A minha sensação é que tudo estava muito voltado para o universo indígena e meio que eu aprendi que a antropologia era isso. Somente no final da carreira tive aulas de antropologia urbana e de antropologia simbólica. O único professor do Departamento 
que era especialista em sociedades afro-americanas, o professor Jaime Arocha, estava de professor convidado na Columbia University, então não consegui ser sua aluna nos primeiros anos. De modo que para mim antropologia era etnologia indígena. Um dia, em uma aula de Antropologia Latino-americana precisávamos falar do tema do trabalho final. Eu disse ao professor Carlos Wladimir Zambrano que iria fazer uma análise sobre alguns povos indígenas do Pacífico colombiano, pois estava indo visitar Orpua, que é um pequeno povoado do Chocó onde moram índios Embera, eu estava por volta do quarto semestre. Foi quando ele me disse: "mas os Emberas moram num território completamente afro, por que você não faz um trabalho sobre as comunidades afro? ". Eu me lembro que fiquei em silêncio e me dei conta que para mim não era claro pensar que os afrodescendentes pudessem ser objetos de pesquisa, e isso me tomou absolutamente. Fui para Orpua e encontrei os Emberá, mas também encontrei comunidades negras de pescadores e caçadores, de mulheres que cultivavam a terra e de seus filhos que os ajudavam. Era um momento, em 1994, em que ainda não tinha chegado lá a luz elétrica, em que era raro ver alguém de fora da comunidade visitando o local. Às noites as pessoas jogavam cartas, tocavam tambor, as crianças brincavam cirandas infantis e cantavam arrullos (música tradicional). Nos dias de minha estadia acompanhei o velório de uma senhora de uma vereda vizinha e as festas do santo. Essa reunião entre música e religiosidade me impactou de um modo absurdo e foi o que passei a pesquisar. Eu tinha 18 anos, para mim essa era minha primeira experiência como antropóloga. Lembro que estando lá, uma noite à luz de velas, escrevi uma carta para Luis Guillermo Vasco agradecendo tudo que tinha me ensinado, era uma carta brega, não me lembro se alguma vez lhe entreguei. Há professores que marcam muito nossas trajetórias. Bom, então dai para frente eu comecei a me interessar basicamente pelos estudos afro-colombianos e ingressei em alguns coletivos de juventude negra em Bogotá. Com uns colegas da Sociologia e do Direito, também negros, formamos a Revista Afroamérica que lográvamos editar com o apoio da secretaria do Bem-estar Universitário. Havia uma conjuntura política de fundo que veio apoiar o adensamento desses estudos: a Constituição Política de 1991 que deu origem à Lei 70 de 1993, sobre as comunidades étnicas. E 93 foi justamente o ano em que eu entrei na universidade. Então, a partir da Constituição e da Lei 70, as comunidades afro-colombianas passaram a ter estatuto de etnicidade e a poder reclamar legalmente os direitos sobre seus territórios, que previamente eram vistos como baldios. Tudo isso me interessou academicamente, mas não só. Eu percebi que embora eu fosse uma menina negra que tinha nascido e crescido em uma cidade negra, eu não necessariamente me percebia como negra. Sentir- 
me negra foi algo que somente percebi quando fui morar em Bogotá, cidade tradicionalmente branca ou branca/mestiça. Foi assim que eu me interessei por tradições afro-colombianas, por pensar a discriminação racial, pensar na invisibilidade do povo negro na história e na educação, sua pobreza e precariedade social em territórios diversos do país e na própria Bogotá: enormes taxas de analfabetismo, abandono pelo Estado, uma história de colonização e de apropriação de seus bens que não parava de se repetir. Então, na Universidade minhas pesquisas tinham um enorme interesse político e foi assim que escrevi minha tese, que na verdade é o que no Brasil se chama de monografia. O que passa é que para nós, naquela época, as monografias eram encaradas como teses, eram enormes, as pessoas faziam pesquisas muito prolongadas, todo mundo fazia meses de campo. Eu tive colegas que demoraram até cinco anos para defender, outros que fizeram teses de dois tomos. Era um grande investimento porque, de alguma forma, essa podia ser a nossa única pesquisa e não tínhamos prazos da Capes nem nada parecido. Digo "última pesquisa” porque naquele momento haviam pouquíssimas pósgraduações de antropologia no país e todas eram caras, não era viável para muita gente fazer pós na Colômbia, por sorte isso tem mudado na última década. Bom, então, eu fiz minha monografia que tinha um pouco menos de 400 páginas.

E: Equal era o tema?

MEDB: Chamou-se Dançando comigo mesma: Identidade, música e irmandade afro-colombiana. Eu tentei demonstrar como a música era um fator identitário muito forte entre a população negra na Colômbia. Estou falando de várias músicas: por um lado, a tradicional que se fazia presente em todo tipo de ritos e festas dos santos padroeiros, nos nascimentos, nas mortes, nos momentos de trabalho, e outras músicas transnacionais que eram grandes fontes de aglutinamento de jovens negros em seus povos e nas cidades: especialmente o hip hop e o reggae. Então, em função desse argumento, fiz uma viagem por diferentes pesquisas que realizei como trabalhos finais de curso e juntei com o campo em Orpua, em Buenaventura e em Bogotá: falei dos jovens polizontes que embarcavam nos grandes navios que vão para os Estados Unidos em busca de melhores oportunidades, dos jovens rastafáris negros de Bogotá e suas músicas de protesto racial, dos grupos de hip hop, das cantaoras tradicionais de jugas e alabaos, das músicas para abençoar as ervas, das músicas de ninar, das canções para despedir aos mortos e por ai vai. No último capítulo, o mais ingênuo da tese (risos) tentei demonstrar as afinidades musicais de ritmos como o blues com o currulao ${ }^{2}$ e as "pegadas de africania" presentes 
neles, que era um paradigma teórico que eu segui em minha tese, acompanhando o pensamento de Jaime Arocha, que foi meu orientador. Enfim, eu queria falar como música e religião eram forjadores de identidade afrocolombiana, inclusive em situações de diáspora, em Bogotá ou outras cidades, para meus conterrâneos que tinham sido deslocados de seus territórios pela guerra no país ou na procura de melhores oportunidades. Essa foi uma oportunidade para falar de migração forçada, invisibilização, discriminação racial e formação de colônias urbanas.

Hoje eu diria que minha tese ficou interessante, mas pouco amarrada. Mas, enfim, os caminhos de procura de identidade não são necessariamente coerentes e gosto de pensar que esse foi o motivo dela ser tão diversa em temáticas (risos). Mas é um texto que me dá orgulho de ter feito porque foi a través dessa procura pelo afro que eu me encontrei na antropologia, me encontrei como jovem negra politicamente falando e cresci como sujeito. Defendi em outubro de 1998 e fiquei dois anos afastada da antropologia porque fui estudar música na Escola Colombiana de Jazz.

No ano 2000 voltei por um convite de meu professor Arocha para trabalhar em uma pesquisa sobre a situação socioeconômica dos afro-bogotanos. Foi quando comecei a acompanhar uma quantidade variada de lugares de sociabilidade de paisanos ${ }^{3}$ meus: comércio informal, camelôs de vendas de frutas e doces tradicionais, ruas, praças, shoppings centers, salões de cabeleireiro, bairros, igrejas, boates. Foi minha primeira experiência na antropologia urbana.

E: Em que momento você se interessou pelos estudos de gênero e sexualidade?

MEDB: Foi na época em que acompanhava as comunidades negras em Bogotá, tudo vem daí. Nesse transito por Bogotá, conheci um grupo de jovens negros homossexuais que vinham de diferentes lugares do Pacífico, entre eles havia duas travestis. Eu percebi que eles tinham uma participação social, entre seus conterrâneos, que me pareceu bastante bem aceita. E percebi que por meio da sua homossexualidade eles conseguiam fazer reivindicações étnico-raciais fortes, tipo, promovendo desfiles de moda e passarela, de penteados afro, de danças folclóricas e modernas, de artesanato tradicional. Eles trabalhavam como cabeleireiros e instrutores de dança e canto, e também vários deles eram universitários, de carreiras diversas. Por meio da música e de suas artes eles representavam aos afro-colombianos em diversos espaços de Bogotá e isso era bem visto na colônia, pois tinham uma importante participação política. O que me surpreendeu disso tudo foi constatar os modos como eles negociavam sua aceitação em 
meio a um grupo que exclui tradicionalmente manifestações de homossexualidade. Eu cresci em uma cidade onde escutei desde criança que os negros não poderiam ser gays, onde havia uma exaltação da masculinidade negra, onde a masculinidade e os mitos da virilidade eram também uma forma de negociar um desequilíbrio em relação aos homens brancos e sua suposta superioridade social. A partir de minha aproximação com esses rapazes eu comecei a me interessar pelos estudos de gênero e sexualidade e por uma literatura que eu mal conhecia. $\mathrm{O}$ fato de eles serem bem quistos no contexto urbano me fez pensar em mudanças sociais e nos espaços possíveis de existência para os sujeitos.

Bom, em 2002 eu fiz esse trabalho de campo e apresentei um projeto para o Programa de Jovens Pesquisadores de Colciências, que é nossa agencia financiadora de pesquisas na Colômbia, e fui favorecida. Foi nessa época também que eu estava apresentando minhas provas para ingressar no mestrado, no Brasil. Pensei que esse seria um ótimo tema para continuar no mestrado, e mais ainda se eu pudesse fazer uma análise comparativa.

E: E esse contato inicial como foi? Foi a partir de quem? Por que você escolheu o Brasil? Você tentou logo o Museu Nacional? Como se deu essa escolha?

MEDB: Olha, vocês decidem se vão colocar isso na entrevista (risos). Eu vim para o Brasil pela primeira vez em 2001, para o Rock in Rio. Foi uma viagem que eu fiz de ônibus desde a Colômbia e que me levou a conhecer Equador, Peru, Bolívia e parte do Brasil, porque entrei pelo Mato Grosso. Mas foi uma correria, pois fiz quase sem parar para poder chegar ao show do Sting no primeiro dia. Fiquei no Rio um mês, amei a cidade, amei a língua, decidi que era o lugar onde queria morar. Essa é a verdade. Eu poderia inventar uma história mais "intelectual" de meus motivos para ter vindo estudar no Brasil, mas na verdade esse foi o principal. Quando voltei à Colômbia entrei em aulas de português e comecei a procurar programas em antropologia. Eu já estava fazendo averiguações para fazer mestrado no Colégio do México, mas mudei meu rumo. Foi assim que conheci o Museu Nacional e sua proposta acadêmica.

E: Você tinha lido antropologia brasileira na graduação?

MEDB: Algumas coisas: Otávio Velho, Roberto Da Matta, Roberto Cardoso de Oliveira e José Jorge de Carvalho. E algumas pesquisas feitas no Brasil, Roger Bastide, especialmente. Em 2002 quando ainda morava em Bogotá, participei da Fábrica de 
Ideias que é um curso de relações raciais em Salvador, Bahia, ali tive aulas com Lívio Sansone, Giralda Seyferth, Osmundo Pinho e Achille Mbembe.

E: Então você se apresentou no Museu Nacional e passou a prova...

MEDB: Apesar de querer morar no Rio, eu me apresentei em vários departamentos: na Federal de Pernambuco, na Unicamp, pois queria entrar no PAGU, no Museu, no IFCS e na UNB, tudo pelo Programa PEC-PG. A primeira resposta que recebi foi da Unicamp, onde não fui aceita. Tristeza total. Mas logo na sequência recebi aceitação no Museu Nacional e foi assim que entrei no lugar que virou minha casa-instituição, mas naquele momento eu não sabia claramente a importância do Museu para a antropologia brasileira. E tive a enorme fortuna de conseguir a bolsa PEC-PG, a única que nesse ano foi dada para antropologia, e o bonito é que consegui com um projeto de pesquisa sobre homossexualidade e raça no Brasil e na Colômbia. Enfim, posso dizer que entrei no Museu um pouco ajudada pelo acaso, e vieram depois uma série de outros acasos, daqueles que constroem uma trajetória que no final nunca é completamente planejada.

No Museu fiz todas as aulas que pude com Giralda Seyferth que desde que a conheci se tornou uma referência de enorme importância para mim e como estava muito interessada pela questão urbana, pedi orientação ao professor Gilberto Velho. Para resumir, como meu interesse era estabelecer uma comparação, acompanhei jovens homossexuais negros por diversos lugares de sociabilidade. Retomei o contato com Osmundo Pinho que me permitiu acompanhá-lo a reuniões de ong's de jovens homossexuais na Baixada Fluminense, e nessas reuniões foi perceptível o quanto eles falavam sobre discriminação racial nos universos homossexuais. Com alguns desses meninos acompanhei várias boates do subúrbio carioca e da Baixada, mas me concentrei em uma boate do centro da cidade, o Buraco da Lacraia.

E: Por que você nunca divulgou sua dissertação? Eu mesmo para ler tive que te pedir pessoalmente

MEDB: Porque eu acho que minha dissertação é cheia de problemas e eu sou exageradamente autocrítica, é por isso que eu publico pouco. Depois que defendi eu senti que ela precisava de muito trabalho e para mim ela não merecia ficar online. Agora que o SIGA nos obriga a ter todas as teses e dissertações online, vou ser obrigada a entregá-la (risos). 
E: Agora eu entendi, porque eu nunca achei (risos). Lembra que o meu primeiro contato foi eu pedindo a tua dissertação? Eu mandei um e-mail gigantesco

MEDB: E eu te mandei, mas assim, muito pontualmente, com vergonha

E: Por que você não gostou?

MEDB: Eu gostei de alguns trechos e foram esses trechos que publiquei. Mas eu acho que na tentativa de fazer comparação, no mestrado, eu me perdi. Porque eu não estava comparando universos comparáveis, entendeu? Em Bogotá, que é uma cidade predominantemente branca, eu pesquisava um coletivo de pessoas negras, em situação de diáspora, que tinha fortes vínculos de conterraneidade. O que a pesquisa me mostrava era como esses jovens negros negociavam seu pertencimento e aceitação como homossexuais nesse grupo a partir de símbolos de etnicidade e de um trabalho político em função desses símbolos. Outras perguntas como sociabilidades nos universos gay, namoros e relacionamentos raramente apareciam, ou apareciam apenas quando eles manifestavam que se sentiam hipersexualizados por homens não-negros com os quais eventualmente se relacionavam. Foram alguns de seus depoimentos sobre o quanto era difícil estabelecer namoros sérios com esses homens que os desejavam basicamente para fazerem sexo, o que me permitiu fazer alguns links. Já no Rio de Janeiro as questões eram outras, mais voltadas para sociabilidades inter-raciais nos mundos gays. Então quando você faz pesquisas distintas, chega a resultados distintos e não adianta querer comparar situações tão diversas. As próprias características étnico-raciais da cidade já são em si muito diferentes. Na final ficaram dois grandes capítulos: um dedicado à etnografia em Bogotá e outro dedicado à etnografia no Rio. Se uma coisa boa ela teve é que eu fiz muito muito trabalho de campo e isso aparece em cada página. As considerações finais foram um tratado antirracista e anticlassista que discutia também as hierarquias de gênero e os valores estéticos dentro das sociabilidades de homens homossexuais.

Hoje em dia, olhando para trás, eu acho que minha dissertação teve uma contribuição ao campo de estudos, especialmente na Colômbia. Estudos que levassem em conta a imbricação entre gênero, raça, classe e sexualidade já eram feitos lá, especialmente pela da professora Mara Viveiros e pelo professor Fernando Urrea, mas naquele momento nenhum dos dois pesquisava homossexualidade. Eram estudos sobre masculinidade, 
sobre relacionamentos inter-raciais, sobre mulheres negras, mas não sobre homossexualidade, tema que o próprio professor Urrea levou a cabo posteriormente. Eu acho que desde esse ponto de vista minha pesquisa foi pioneira, só que como eu nunca mostrei nada, nunca ninguém soube (risos).

Bom, dali eu publiquei alguns artigos. ${ }^{4}$ Mas estando aqui, não consegui dialogar muito com as pessoas dessa área de estudos na Colômbia, e acontece que tampouco consegui dialogar nem mesmo com as pessoas que trabalhavam esse campo aqui no Brasil, por volta de 2004. Essa foi minha primeira aproximação aos estudos de interseccionalidade que hoje tem ganhado tanta importância no cenário acadêmico e político.

E: Você mudou de tema para o doutorado, quais foram os motivos?

MEDB: Eu desejava continuar no campo dos estudos de gênero e sexualidade. Para aquele momento, 2005/2006, eu já era uma boa leitora de teoria queer e começava a me adentrar com força na literatura feminista, especialmente a pós-estruturalista. Mas o tema em si foi um presente que o campo da dissertação me deu. Um dia dançando e pesquisando, no Buraco da Lacraia, conheci um rapaz que me disse que era ator pornô. Vemo-nos duas vezes mais depois daquele primeiro encontro e da última vez ele me disse que pretendia parar de gravar pornô porque sua mãe estava muito triste com esse fato e ele teria lhe prometido. Tivemos conversas não muito longas, mas muito marcantes.

Eu precisava fazer um projeto para o doutorado e comentei a Gilberto Velho que eu tinha duas ideias de tema: fazer uma etnografia da prostituição noturna de travestis na Avenida Dutra - pois naquela época houve diversas notícias de assassinatos de travestis que até renderam um documentário feito por Wagner de Almeida e eu me interessava pela questão da violência de gênero e homofóbica - ou fazer uma etnografia do universo de produção de filmes pornô no Brasil. Gilberto ficou preocupado com o primeiro tema, imaginando que eu poderia sofrer perigos ou mesmo ser morta fazendo campo à noite, circulando na Avenida: "você nem é da região, nem é brasileira, é menina, tem sotaque, de jeito nenhum". Sem dúvida ele tinha razão em que se tratava de um campo arriscado, pelo menos para uma observação participante in locus que era o modo como eu queria fazer. Já o segundo tema ele achou muito apropriado, ele adorou, na verdade. Ele deu um sorriso e disse: "ótimo". Não sei se vocês chegaram a conhecer Gilberto Velho, ele tinha um humor incrível, uma maneira de falar, uma corporeidade que era muito solene e muito engraçado. 
Estudar o universo de produção de pornografia me permitiria adentrar em um tema caro para ele que é o estigma social e as carreiras desviantes. Foi assim que comecei a ler estudos sobre pornografia, alguns feitos no Brasil, fiz as disciplinas e corria atrás da possibilidade de conhecer as pessoas e entrar no campo.

\section{E: Enão foi fácil}

MEDB: Não foi nada fácil, especialmente no começo. Eu comecei correndo atrás por meio do Orkut que era o que tínhamos nesse momento. Eu escrevia para tudo que era gente e se dizia associada a esse meio. Vários atores e atrizes tinham sua própria página, mas nunca nenhum deles me respondeu, quem me respondia eram geralmente garotos que queriam fazer pornô. Demorei muito para entrar e o Gilberto já estava começando a ficar impaciente: "Elvira, mas é difícil chegar nesse universo, qual é o seu plano B?". Eu disse: "não tem plano B, eu vou chegar lá, pode crer". O plano B que ele me propôs foi fazer uma análise dos filmes através de seus enredos e de suas estéticas tentando identificar o que eles teriam a dizer sobre gênero, sexualidade ou, inclusive, sobre brasilidade. Eu achava isso muito interessante e eram temas que certamente eu pretendia discutir, mas não queria que minha tese fosse basicamente sobre representações. Então continuei tentando. Naquele momento o comércio era de DVD's e os DVD's na parte de atrás tinham o endereço da caixa postal das empresas, eu escrevi para todas, inúmeras vezes, mas tampouco me responderam.

Eu ligava para as produtoras, mas descobri que muitas não eram produtoras senão distribuidoras e por tal não tinham conhecimento nem autorização para me permitir uma maior proximidade. Eu me tornei uma grande consumidora de pornografia brasileira alugando filmes ou comprando nos camelôs. Então fiz uma lista dos elencos dos filmes, dos diretores, das modalidades, de todas as pessoas que apareciam nos créditos. Percebi que algumas pessoas mudavam de nome de um filme para outro, eu já conseguia identificar coisas como essa.

O milagre da entrada no campo se deu por uma amiga cujo marido era jornalista que acabava de conhecer a Rita Cadillac. Meu primeiro contato foi recebido por seu agente que me pediu enviar o projeto de pesquisa. Enviei junto de uma carta do Gilberto assinando como orientador e Decano do PPGAS/Museu Nacional. Dias depois, ao telefone, o agente negou a possibilidade. Mas eu consegui um número de telefone e foi ali que a magia aconteceu. Eu liguei imaginando que falaria com outro agente, mas quem atendeu foi a própria Rita. Emocionada, tremendo e gaguejando expliquei o motivo de 
eu procurá-la. Era domingo. Ela amavelmente me convidou a visitá-la em sua casa no dia seguinte. Essa mesma noite tomei um ônibus para São Paulo. Sem conhecer a cidade cheguei a sua casa às $10 \mathrm{~h}$ como ela tinha sugerido e lá fiquei o dia todo. Durante o dia, ela tomou seu celular e ligou para todo mundo, para todos aqueles que eu tinha tentado aproximação sem sorte: atrizes, atores, diretores, produtores. "Oi, aqui a Rita, vou dar teu telefone para uma menina colombiana que faz pesquisa e quero que você dê entrevista para ela, ok? ”. Eu saí dali com meu diário cheio de números e, ainda, sai com um convite para assistir ao lançamento do filme de Mateus Carrieri que seria ao dia seguinte em um bar em São Paulo.

Foi assim que eu fiquei uma semana em São Paulo, tinha levado roupa para dois dias, mas fiquei uma semana. Fiz algumas entrevistas com pessoas que eu sentia que já conhecia de tanto que havia pesquisado sobre elas. Continuei indo duas vezes por mês. Cada vez que podia, me hospedava num flat no centro da cidade no qual morava um número grande de pessoas do pornô, ali passei grande parte de meu campo. Depois de vários meses indo e vindo decidi que precisava morar em São Paulo. Os últimos meses, morei na casa de três antropólogas e pesquisadoras de gênero e sexualidade: Isadora França, Ana Paula Vencato e Regina Facchini, ganhei três ótimas amigas e três ótimas interlocutoras.

E: Eu acho você ou Ana Paula citam no agradecimento a história de quando tomavam café da manhã...

MEDB: Eu (risos). O fato é que no café da manhã nós quatro falávamos de nossos temas, falávamos disso o tempo todo, desde que acordávamos. Isadora, Ana Paula e eu estávamos fazendo campo e a Regina já estava escrevendo a tese e tinha um prazo para defender. Eu gosto de dizer que a Regina me co-orientou, nós discutíamos muito, ela me co-orientou no café da manhã, estar com elas foi uma experiência maravilhosa. Elas me apresentaram Jorge Leite Jr., cujos trabalhos sobre pornografia eu já tinha lido, e ele se tornou outro importantíssimo interlocutor e amigo.

E: Quais você acha que foram as principais contribuições de sua tese para o campo de estudos em pornografia, e em gênero e sexualidade

MEDB: É difícil responder, pois a ideia de contribuição não é algo do qual a gente possa ter uma clara percepção. De repente um trabalho contribui de forma distinta para cada leitor, cada pessoa se inspira em um ponto, ou inclusive em insights que aparecem dos 
quais o autor nem tinha plena consciência. Então, é difícil, mas se tiver que responder algo, diria que minha contribuição é de caráter etnográfico. Eu consegui fazer um estudo sobre pornografia não através da análise dos filmes, mas através do acompanhamento dos sujeitos, de conhecer seus discursos, de observar seu trabalho, de conhecer as ideias e valores que eles mesmos possuem a respeito desse labor. Fiquei tão próxima de algumas pessoas que posso dizer que consegui conhecer suas emoções, entender seus aprendizados para o exercício da carreira, os efeitos dessa escolha no âmbito familiar, social, amoroso e subjetivo. Também percebi como nessa rede existiam cadeias de afeto, amizade e cuidado para dar suporte a quem precisasse, mesmo quando esses afetos algumas vezes - estavam mediados simultaneamente por relações comerciais.

Eu tentei transmitir essas emoções no texto. Uma coisa importante foi perceber que esse universo, como qualquer outro, está repleto de modos de hierarquização dos indivíduos e vários dos motivos pelos quais os sujeitos eram submetidos a avaliação moral pejorativa tinha a ver com o tipo de sexo que faziam dentro e fora do mercado pornô. Quer dizer, do elenco se exigia que fossem pessoas que gostassem muito de sexo e fizessem com prazer e com ousadia, "não tendo frescuras" para certas práticas. Ao mesmo tempo se exigia uma certa "pureza", um controle a respeito de gostos para que fossem o mais heteronormativos possível (para os homens apenas) e o menos "bizarros" em geral.

Finalmente, eu destacaria duas coisas importantes: por um lado, perceber que a rede do pornô vai para além do pornô mesmo e envolve uma série de outros tentáculos do mercado do sexo e perceber que eu não poderia analisar o primeiro sem entender as características das relações com esses tentáculos. Por outro, o campo me permitiu discutir práticas sexuais a partir da observação direta das mesmas e desse modo analisar os enunciados de gênero e sexualidade presentes nelas, assim como os modos como a partir do sexo é possível falar de classe e de raça. Uma pergunta que me acompanhou no campo foi o que essas práticas teriam a dizer sobre normatividade e sobre transgressão? O sexo no pornô é tão transgressor assim? Eu consegui concluir várias coisas a esse respeito, por exemplo, aquilo de que norma e transgressão sempre estão da mão, sendo possível ser transgressor no âmbito da sexualidade e simultaneamente, com a mesma prática, reiterar normativas de gênero, ou exacerbar estereótipos regionais, raciais ou nacionais. O pornô é um dos territórios mais criativos para brincar com a ideia de diferença, e se isso pode ser até certo ponto bem subversivo, quando essa diferença se traduz em desigualdade, ele cai novamente na normatividade.

$\mathrm{Na}$ verdade, eu acho que a gente é muito político e exige muito do pornô. E aquele mais 
mainstream que eu acompanhei não está pensando em fazer política, ele se vê a si mesmo como um produto de consumo e sua finalidade é vender-se como um material para o entretenimento.

E: Como se deu essa passagem de terminar o doutorado para a seleção como professora?

MEDB: Após defender o doutorado eu trabalhei no CLAM (Centro Latino-americano em Sexualidade e Direitos Humanos) da UERJ e um ano depois entrei no pósdoutorado no Pagu, sob a supervisão da professora Maria Filomena Gregori e com apoio da Fapesp - eu sempre digo que sempre quis voltar ao Pagu porque em 2002 não consegui (risos).

A ideia era fazer uma pesquisa sobre uma temática da pornografia que acompanhei tangencialmente no campo de doutorado, mas que não pude aprofundar: produções consideradas de fetiche e bizarra, as pessoas e as ações em torno delas. Eu achava que iria poder retomar meus contatos e fazer um campo tranquilo, mas na verdade, novamente tive dificuldades para me inserir. Isso porque naquele momento houve uma queda na indústria pornô, várias empresas fecharam, muita gente que eu conheci tinha saído desse mundo. Enfim, houve uma reconfiguração enorme do mercado que alguns atribuem à pirataria e à efervescência do pornô na Internet. Outros pensavam que esse era o fim do pornô no Brasil, mas isso obviamente não aconteceu, como diz o ditado: nada morre, tudo se transforma. Minha dificuldade foi acessar as redes de produção de filmes de fetiche que eu não conhecia previamente e que, ainda, trabalhavam de modo sigiloso, especialmente os que produziam filmes com animais.

Bom, sobre essas pesquisas eu tenho escrito apenas dois artigos e estou preparando um livro sobre a ideia da humilhação nessas produções que espero terminar o mais breve possível. O primeiro artigo se chamou "sexo com animais como prática extrema no pornô bizarro" e o segundo "O espetáculo da humilhação, fissuras e limites da sexualidade". Eu fui muito inspirada pela noção de "Limites da Sexualidade" da Maria Filomena Gregori e nesse último artigo consegui condensar as ideias, a meu ver, mais bacanas que já tive ao pensar as questões da violência na sexualidade, dentro da discussão sobre consentimento e abuso, que é a ideia de fissura como aquele momento em que é possível transpassar as fronteiras da representação do ato ao ato mesmo.

Quando estava no segundo ano de pós-doutorado saiu a possibilidade de fazer o concurso para docente no PPGAS/Museu Nacional. Gilberto velho acabava de morrer 
e abriram uma vaga logo depois.

E: Você imaginou que seria professora do lugar em que estudou?

MEDB: Nunca, juro por Deus, e digo isso sem falsa humildade. Quando era aluna, eu nunca imaginei que poderia ser professora do lugar que me formou, pois não sentia que estava à altura de mulheres como Olívia Gomes da Cunha ou de Giralda Seyferth. E quando me inscrevi no concurso eu tinha o intuito de fazer meu melhor esforço, mas no começo achava pouco provável "subir ao pódio". Mas a verdade é que desde que me inscrevi até o dia da prova escrita eu estudei como nunca imaginei que poderia estudar, quatro meses de muita leitura, e enquanto mais estudava e preparava profundamente ponto por ponto, como obsessiva que sou, comecei a achar que minha candidatura podia ser competitiva, eu não tinha um grande currículo, mas estudei feito maluca.

E: Fale um pouco dessa sua atuação em sala de aula. Como é isso? A gente pensa o Museu como um campo que não era dominado pelo tema de gênero/sexualidade e vemos a possibilidade agora de uma abertura pela sua presença lá, com vários alunos pesquisando a esse respeito. Essa expansão maior para o Museu que é muito conhecido por outros temas, mas que não era reconhecido nitidamente por esse campo ou que na verdade não discutia gênero e sexualidade.

MEDB: Olha, sim e não. Eu não posso dizer que abri um campo no Museu Nacional, porque isso seria muito injusto, sinceramente. Na verdade, mesmo sem ser um especialista em gênero, Gilberto Velho orientou várias teses sobre gênero e homossexualidade: Carmem Dora Guimarães, Maria Luiza Heilborn, o próprio Luiz Fernando Dias Duarte que não defendeu tese sobre o tema, mas que é uma referência e que por sua vez, foi orientador do Sergio Carrara. Gilberto orientou também Maria Dulce Gaspar que pesquisou prostituição em Copacabana, orientou Jane Russo, Andrea Moraes.

Luiz Fernando Dias Duarte foi o primeiro professor que no Museu Nacional levou mais a sério os estudos da sexualidade em interfaces muito interessantes como ciência, saúde, psicanalise, geração, ele é uma pessoa que tem tido uma inserção enorme no campo da sexualidade ao longo de seu percurso. Temos também Adriana Vianna que entrou ao PPGAS/MN quando eu estava na metade de meu doutorado. Adriana dava aulas de gênero, tem orientado várias teses e dissertações nessa área em interface com a temática 
da violência e da antropologia do Estado. Desde os anos oitenta a professora Bruna Franchetto publicou artigos sobre gênero e feminismo. Ela é uma linguista importante no país e tem orientado várias teses sobre gênero no mundo ameríndio. Nos últimos anos entrou a professora Luisa Elvira Belaunde, uma etnóloga peruana que tem trabalhando sobre gênero na Amazônia e tem coisas ótimas publicadas a esse respeito, um dos seus trabalhos que eu mais gosto dela é sobre menstruação.

Então são várias entradas ali se somando. Eu acho que o que eu tenho conseguido fazer no Museu é afiançar algo que já existia. Junto do Luiz e da Adriana conformamos o Nusex (Núcleo de Estudos em Corpos, Gênero e Sexualidade) e começamos uma dinâmica intensa de palestras, seminários e discussões as mais diversas e que já tem rendido várias defesas de dissertações e teses maravilhosas.

Eu acho que minha contribuição tem sido essa e aprofundar nas aulas os estudos sobre interseccionalidade. Essa temática me acompanha desde o mestrado e consegui aprender mais a esse respeito quando estive no Pagu, pois a interseccionalidade é fundamental, por exemplo, nas pesquisas de Adriana Piscitelli, Isadora França, Regina Facchini, Mariza Correia.

E: Como foi seu processo de se aprofundar nesse paradigma?

MEDB: Olha, eu tenho a sensação - e posso estar errada - mas eu tenho a sensação de que até poucos anos atrás, no Brasil, quando se falava de interseccionalidade as referências eram especialmente Avtar Brah e Anne McClintock. Das autoras nacionais, as mais relevantes e sempre citadas eram Adriana Piscitelli e Laura Moutinho. Também sempre fazíamos referência à contribuição imensurável de Néstor Perlongher em $O$ negócio do Michê, e aos trabalhos de Mariza Correia, sobre as mulatas, e de Peter Fry.

Mas raramente ou talvez nunca eu vi citadas a rigor as feministas negras, pós-coloniais, chicanas, islâmicas e as decoloniais. Eu me propus conhecer essa literatura mais a fundo e comecei a oferecer em minhas aulas as discussões de todos esses feminismos, entendendo suas propostas, suas críticas ao feminismo central, suas contribuições, seus pontos de inflexão. Eu acho que depois de ler mulheres como Angela Davis, Gloria Anzaldua ou Saba Mahmood, só para mencionar algumas, minha cabeça nunca mais foi a mesma. De Anzaldua e Mahmood encontrei algumas traduções ao português em revistas importantes de antropologia e de gênero, mas ainda assim eu não percebia que elas fossem grandemente influentes nos estudos sobre interseccionalidade nacionais. Esse primeiro curso que ofereci sobre interseccionalidade, juntava essas leituras com 
outras sobre queer latino e migração em autores como Lionel Cantu, e, finalmente, com bibliografia sobre teoria crip, que pensa a deficiência física como marcador social da diferença.

Além disso, eu estou muito na procura de interpretar as emoções na mão da interseccionalidade. Para mim sempre tem sido fundamental procurar diversas perspectivas para a análise de qualquer fenômeno, nunca estou cômoda quando passo muito tempo em um lugar só. Isso pode ser ruim e bom. Ruim porque se corre o risco de ser diletante e de nunca se especializar realmente em nada, e bom porque você consegue ter outras perspectivas. Então a fenomenologia está me ajudando muito para pensar questões como o nojo e o desprezo, e atos como a humilhação, pensando-os como emoções que organizam social e moralmente nossos valores, e pensando que é possível pensar que são emoções a partir das quais é possível fazer leituras de raça, gênero e sexualidade.

E: Qual é a principal marca do seu trabalho? E que correntes, disciplinas, autores/as e professores/as influenciaram sua formação e seus trabalhos?

MEDB: Sobre os professores que me influenciaram, eu acho que já respondi ao longo da entrevista, destacando novamente meus três orientadores: Jaime Arocha, Gilberto Velho e Maria Filomena Gregori. A eles devo somar outros docentes que, embora não foram meus professores diretamente, sempre têm sido muito influentes nesse campo do gênero e sexualidade. Eu trabalhei no CLAM e lá aprendi com cada um dos pesquisadores, Malu Heilborn, Sergio Carrara, Jane Russo, Horacio Sívori. Na USP está Julio Simões de quem sempre temos muita coisa para aprender. Leio o que produzem na UFSC, o ensino do gênero lá é de ponta e acho que todos nós seguimos a Revista de Estudos Feministas.

Também tenho sido influenciada por professores de outras áreas do conhecimento, não só de gênero e sexualidade, pessoas que estudam relações raciais como Kabengele Munanga, pesquisadoras Jurema Werneck e Sueli Carneiro, professores de teoria antropológica que tive no meu percurso como Otávio Velho, Marcio Goldman, Antonadia Borges e Eduardo Viveiros de Castro ou de Pensamento Social Brasileiro, como Moacir Palmeira.

Sobre a principal marca de meu trabalho eu teria que dizer que até agora tenho me interessado intelectualmente apenas por temáticas que me movimentam politicamente, talvez esse seja o motivo de meu engajamento: raça, racismo, gênero, desigualdades de 
gênero, orientação sexual, violências por homofobia. Meus últimos anos estudando prazeres e perigos na sexualidade, para utilizar um termo da Maria Filomena, passam muito por aí. A isso se soma um interesse muito grande por conhecer os mundos e imaginários de pessoas que se engajam em formas de vida vistas como outsiders, nisso aparece a marca do Gilberto em mim e se mistura com minhas tentativas de analisar academicamente e simultaneamente apoiar politicamente as reivindicações de sujeitos que transitam na abjeção, como diria Butler.

Outra coisa que eu acho que tenho procurado ao longo de minha carreira que nem é tão longa assim, é perseguir um certo nomadismo teórico, tentar não ficar cômoda nos mesmos autores, por mais que eles sejam adequados ou incríveis e por mais que eu goste. Tipo, eu fiz um artigo sobre o dark room do Buraco da Lacraia e estava interessada em analisar o tipo de interações que acontecia naquele lugar, mas não queria partir de uma descrição rasa sobre as práticas sexuais. Então corri atrás da literatura da antropologia ritual, alguns autores como Tambiah, Paul Stoller e Herzfeld me ajudaram na interpretação, e especialmente ler Austin e sua teoria sobre os atos da fala e os modos como diversos acadêmicos tem utilizado suas ideias para as análises do ritual. Eu acho que minha procura nesse artigo foi submeter uma "baixa temática" - chamemos assim, porque ainda há quem acredita que a sexualidade é um tema pouco legítimo para a pesquisa séria - a um exame a partir da antropologia mainstream.

A ideia sobre as fissuras em meu campo sobre fetiches de humilhação também veio de uma série de leituras que não apenas as de gênero e sexualidade. Se por um lado, as ideias de Anne McClintock, mas, sobretudo as noções da Maria Filomena sobre "Limites da Sexualidade" e "Empreendimentos de Risco" foram fundamentais, eu acho que só consegui formular a ideia sobre as fissuras quando misturei isso com a leitura de Roland Barthes e de Richard Schechner. Ou seja, foram fundamentais as ideias de Schechner sobre a "segunda realidade" ou a "realidade de modo diferente" que acontece nas encenações, assim como as ideias sobre a eficácia da performance. Schechner diz que existem momentos de máxima eficácia e isso me ajudou a pensar que na humilhação, a máxima eficácia se atingia a través das fissuras. Mas isso foi porque li “ $\mathrm{O}$ mundo do catch" de Roland Barthes onde ele diz que esse esporte se baseia em uma estética exterior da tortura, onde o importante é o que se vê e não o que se crê. Na humilhação seria o contrário: o espetador precisa acreditar no que vê, mesmo que saiba que está consumindo, de fato, uma encenação. Eé nesse "fazer crer" que acontecem as fissuras. É mais ou menos isso. Eu gosto muito da literatura queer, por exemplo, mas de um momento para outro comecei a sentir que ela sozinha não dava conta de coisas que me 
interessavam, e assim por diante.

E: O que você percebe de positivo na nova geração de pesquisador_s?

MEDB: Olha, eu acho que vocês estão em um momento maravilhoso em relação à expansão dos estudos de gênero e sexualidade nas universidades ao longo do país. Há núcleos fundamentais pelo Brasil todo, que têm conseguido que nossa área se afiance para além do circuito sul-sudeste: Leandro Collins em Salvador, Camilo Braz e Luiz Mello em Goias, Fabiano Gontijo no Pará, Sandra Sousa no Maranhão, Elisete Schwade, Carlos Guilherme do Vale, Roseli Porto e Berenice Bento em Natal, entre outras pessoas que agora escapam de minha memória.

Então eu acho que o primeiro aspecto positivo é que vocês têm muitos mais espaços de interlocução: o ENUDS, GT’s na Anpocs, o Fazendo Gênero, o Desfazendo Gênero.

Para além disso, eu vejo uma proliferação de temáticas que são também muito interessantes e a prova disso são os diversos GT's, seminários e simpósios em cada um de nossos eventos. Não só na antropologia e sociologia, também na educação, na psicologia, filosofia e linguística, vemos uma onda de pesquisas enormemente interessantes. As interfaces também são algo a destacar: à literatura mais central do gênero e da sexualidade devemos somar os links que vocês vêm fazendo com a antropologia da saúde, do Estado, das emoções, da interseccionalidade, da antropologia urbana, da migração, do mercado, da pobreza, da violência. Eu acho que vocês mais do que nunca têm um enorme leque de questões, legitimadas pelos pares antropólogos, para pensar as sociedades.

E: A partir da sua experiência, quais são os dilemas atuais dessa nova geração de pesquisador_s?

MEDB: Eu acho que o dilema mais preocupante é o florescimento de um conservadorismo que pode vir a ter muita mais força política e tentar atrapalhar nosso trabalho de pesquisadores. Eu não quero ser apocalíptica, mas tenho muito medo do que possa passar se todos esses bolsonaros, malafaias, cunhas e felicianos da vida se tomam o poder mais um pouco. Temo que o dinheiro das entidades financeiras decida ir basicamente para as ciências exatas. Se eles quiserem cortar orçamentos, como já começou a acontecer, o farão nas ciências humanas e sociais, e dentro delas, os estudos de gênero e sexualidade não serão prioridade. 
Temo que estejamos nas mãos do Estado, e o que estamos assistindo é uma investida das igrejas pentecostais, evangélicas, neopentecostais se tomando o poder. Já barraram muita coisa: o kit homofobia, as leis sobre o aborto, já empreenderam cruzadas morais como a cura gay. O país está muito torto e inclinado para a direita e gênero e sexualidade são dois dispositivos onde muito se concentram os embates dos poderes e dos conservadorismos. Cada vez que uma mulher é estuprada, as mídias e grande parte do povo acreditam que ela está mentindo; cada vez que uma pessoa negra denuncia uma experiência de racismo, é desacreditada ou tratada como ressentida.

Eu acho que o que vem para todos nós como desafio é lidar com esse panorama nojento conservador. Já dois alunos muito próximos foram acusados nas mídias sociais de gastar o dinheiro dos impostos e da nação fazendo pesquisas de "putaria", se perguntavam como a capes tinha financiado isso? Não está fácil.

Por outro lado, eu acho que um assunto que tem me parecido muito frequente em todas as novas gerações de antropólogos, mas que eu vejo em primeira mão na gente de nossa área é uma certa pressa por publicar. Eu sei que isso é resultado do produtivismo ao qual somos submetidos pelas avaliações da capes, e no desespero de construir um lattes para a hora de fazer concursos. Há dúzias de professores também nesse pique do produtivismo publicando como coautores os trabalhos de pesquisa de seus alunos, o que eu não consigo ver com bons olhos. No caso dos alunos, eu não posso criticar isso, à final, todos queremos garantir para nós uma boa inserção acadêmica e umas boas possibilidades de trabalho. Devemos apenas estar atentos a que esse produtivismo não nos leve a acreditar que qualquer ideia é digna de publicação, que a pressa não nos tire a responsabilidade com o trabalho de campo e com a profundidade das análises.

\section{Notas}

1. O comitê editorial da Revista Equatorial agradece à entrevistada a autorização para publicar esta entrevista e ao/às entrevistador/as a realização da entrevista.

2. Jugas, alabaos, arrullos e currulao são ritmos musicais tradicionais do Pacífico colombiano.

3. Conterrâneos, pessoas da mesma região.

4. "Buraco da Lacraia: Interações de raça, classe e gênero"; "Jerarquias y Resistencias: raza, género y clase en universos homosexuales" e "Além de preto, veado! Etiquetando experiências e sujeitos nos mundos homossexuais". 